International Journal of Biology, Pharmacy and Allied Sciences (IJBPAS) 'A Bridge Betuen Caboratory and QRando'

WWW.ibpas.com

\title{
AWARENESS ON DIABETES MELLITUS AMONG ADULTS - A QUESTIONNAIRE SURVEY
}

\section{RANJETH RAJAN KV ${ }^{1}$, V.VISHNU PRIYA ${ }^{2 *}$, LAVANYA PRATHAP ${ }^{3}$ AND R.GAYATHRI ${ }^{4}$}

1: Saveetha Dental College and Hospital, Saveetha Institute of Medical and Technical Sciences, Saveetha University, Chennai- 600077.

2: Department of Biochemistry, Saveetha Dental College and Hospitals, Saveetha Institute of Medical and Technical Sciences, Saveetha University, Chennai- 600077

3: Assistant Professor, Department of Anatomy, Saveetha Dental College and Hospitals, Saveetha Institute of Medical and Technical Sciences, Saveetha University, Chennai- 600077

4: Department of Biochemistry, Saveetha Dental College and Hospitals, Saveetha Institute of

Medical and Technical Sciences Saveetha University, Chennai- 600077

*Corresponding Author: E Mail: Dr. V.Vishnu Priya: vishnupriya@saveetha.com

Received 19 ${ }^{\text {th }}$ March 2021; Revised 25 ${ }^{\text {th }}$ April. 2021; Accepted 20 ${ }^{\text {th }}$ May 2021; Available online $1^{\text {st }}$ Aug. 2021

\section{https://doi.org/10.31032/IJBPAS/2021/10.8.1068}

\section{ABSTRACT}

Diabetes Mellitus (DM) is a disorder in which blood sugar levels are abnormally high because the body doesn't produce enough insulin. Polyuria, Polyphagia and Polydipsia are seen in DM. The aim of the study is to assess awareness on DM among the older generation. The population taken for this study is 100 participants from Tamil Nadu. The survey is conducted among the participants using a standardised questionnaire administered to the participants through online google forms link. Method of representation of data is Pie chart, Bar Diagram. The sampling method used here is a convenient sampling method. Standardized questionnaires are based on knowledge, time management, interest and understanding. The data collection software used is SPSS Software. $52 \%$ of the participants were female and $48 \%$ of the participants were male. $14 \%$ of the participants agreed that insulin lowers blood glucose level. 34\% of participants experienced polyphagia in diabetes. The participants were aware of the symptoms associated with diabetes mellitus. Both male and female population were equally aware about diabetes mellitus. More awareness camps, workshops, may be conducted to 
create awareness on risk factors, complications of diabetes and its associated disorders. Awareness on lifestyle modifications is the need of the hour for both young and older generations.

\section{Keywords: Diabetes Mellitus; lifestyle modifications; risk factors; diabetic foot; diabetic} cataract; online survey

\section{INTRODUCTION}

Diabetes Mellitus (DM) a chronic disease associated with abnormalities and high levels of glucose in blood [1]. Problems of Diabetes Mellitus are not homogenous. Salient features can be polyuria, polyphagia and Diabetes cataract [2]. Older people worldwide are disproportionately affected by diabetes and are more likely to have co-morbidities and disabilities [3]. Guidelines for management, developed by the American Diabetes Association, are not targeted for this population [4]. DM may increase risk for the developing cognitive impairment, including Alzheimer disease and also vascular dementia, has prompted interest in whether diabetes treatment can prevent cognitive decline [5]. Glycemic control has been proposed as a potential mechanism to improve cognitive outcomes among those with DM.A plethora of quantitative research has investigated self-management issues, with little change to outcomes [6]. This pleads for consideration of a new diabetes education model, which includes consideration of experiences within clients worldviews. Recently, numerous algorithms are used to predict diabetes, including the traditional machine learning method,such as support vector machine decision trees, logistic regression and so on [7]. With the development of living standards, diabetes mellitus is increasing commonly in people's day to day life [8]. Therefore, how to quickly and accurately diagnose and analyze diabetes is a topic worthy studying [9]. In medicine, the diagnosis of diabetes is according to fasting blood glucose, glucose tolerance, and random blood glucose levels [10, 11].

In the article "lived experience of Diabetes among older people" by Sharon .R the background of this literature is the older people worldwide are disproportionately affected by Diabetes and more likely to have disabilities. Overweight and obesity are driving the global diabetes epidemic [12, 13]. Older people consume an increasing amount of medication. They affect the majority of adults in most developed countries and are increasing rapidly in developing countries. In addition, even a modest amount of weight gain during adulthood substantially increases the risk of diabetes in Asians [14]. According to the IDF report, countries like China, India and the United States have top the list for the most cases of diabetes; around 24.4 
million Americans had the disease in 2013 [15]. Diabetes prevalence has been rising more rapidly in middle- and low-income countries [16]. Diabetes is a major cause of blindness, kidney failure, heart attacks, stroke and lower limb amputation [17]. Diabetes is widely recognized as a significant risk factor for the development of heart failure and is an independent risk factor for increased mortality among individuals with heart failure. It is also established that the incidence of heart failure rises sharply with age [18].

Previous advanced studies on nanoparticles [19-22], research on natural compounds [23-29] enriched my Knowledge to take up research on Diabetes Mellitus [30]. Necessity of the research is to create awareness on risk factors in Diabetes Mellitus and also insulin deficiency. Our analysis is based on a comprehensive health check for older people affected by Diabetes. Hence, we aimed to look at a large variety of patient- and doctor-related factors that predict the simultaneous and regular use of five and more chronically prescribed medications [31]. We also wanted to determine the amount of selfreported medications taken by older primary care patients having diabetes. The aim of the study is to assess the awareness of Diabetes Mellitus among the older generation.

\section{MATERIALS AND METHOD:}

The Study setting used here is an online setting. The population taken for this study is 100 participants from Tamil Nadu. The survey is conducted using a standardised questionnaire. Data was collected and tabulated. The data collection software used is SPSS software. The results of this study in terms of individual behavior and awareness of Diabetes Mellitus among the older generation are comparable with similar studies conducted in other countries. The MCQ type questions are prepared with choices with the help of google forms, and all the questions were shared. For this research 12 self structured questionnaires were created. Output variables can be risk factors, food habits, aged people. The sampling method used here is a convenient sampling method. Method of representation of data is Pie chart, Bar Diagram. Statistical tests used are Descriptive statistics. Independent variables can be Age, Weight, Gender, Risk factors, dietary habits, lifestyle modifications. dependent variables can be awareness, interaction, knowledge, attitude, perceptions. This study is approved by the Institutional Review Board, Saveetha Dental College, Chennai.

\section{RESULTS AND DISCUSSION}

In the current study the questionnaire was circulated on the basis of knowledge, 
attitude and practice. The data is collected and statistically analysed. $34.00 \%$ are in age groups between $25-40 ; 19 \%$ are in age groups above 40 ; about $23.00 \%$ are in age groups between $15-25 ; 24 \%$ are in age groups above 60 Years (Figure 1). 52\% of the participants were female and $48 \%$ of the participants were male (Figure 2). Majority of participants (34\%) perceived always feeling hungry.14\% of the participants agreed that insulin lowers blood glucose level (Figure 3). 45\% believed diabetes is called a silent killer. $34 \%$ of participants experienced polyphagia in diabetes (Figure 4). Majority of participants (31\%) were aware that diabetes causes damage to the brain. $45 \%$ of participants were agreed that diabetes is a silent killer (Figure 5). 18\% of participants are aware of diabetic cataract (Figure 6). $18 \%$ of participants felt that cardiovascular disease associated with Diabetic mellitus (Figure 7). $34 \%$ of participants were agreed that wound healing is delayed in diabetes (Figure 8). 25\%- agreed 60mg/dl ; $20 \%$ - agreed $70-80 \mathrm{mg} / \mathrm{dl} ; 16 \%$-agreed all $90 \mathrm{mg} / \mathrm{dl}, 38 \%{ }^{-}$agreed $90 \mathrm{mg} / \mathrm{dl}$ (Figure 9).Carbohydrates rich food causes diabetes. $38 \%$ of females reported that easy to miss symptoms and $27 \%$ of male reported that easy to miss symptoms (Figure 10). Participants were aware of medication used in Diabetes. 39\% of females reported nerve damage and $22 \%$ of male reported nerve damage (Figure 11). $70 \%$ agreed that coffee with sugar is bad for diabetes. $29 \%$ of females reported metformin; and $17 \%$ of male reported metformin (Figure 12).

Diabetes Mellitus affects the older generation. Harmful effects of diabetes can be muscle atrophy, limiting physical activity, increasing the risk of falls, risk of postural instability and Lifestyle modifications. Regularly Exercising, Avoiding all Forms of Sugar, Adding Cinnamon to Foods and Beverages, fasting blood sugar (FBS) test. Diabetes prevalence has been increasing among the elderly, and it is estimated that the 3.5 million individuals aged $\geq 65$ years with diabetes in 2000 will increase to 5 million individuals. The limitations for this study can be Survey fatigue, Online survey, Increase in sample size, and Inclusion of more criteria. We are confident that our cohort had diabetes, as our criteria for defining diabetes has been reported to have a specificity of $98 \%$. Although still in the very early stages of development, cell therapy is one of the biggest hopes towards developing a cure for diabetes, especially for type 1 diabetes. Replacing the missing insulin-producing cells could potentially recover normal insulin production and cure patients. 


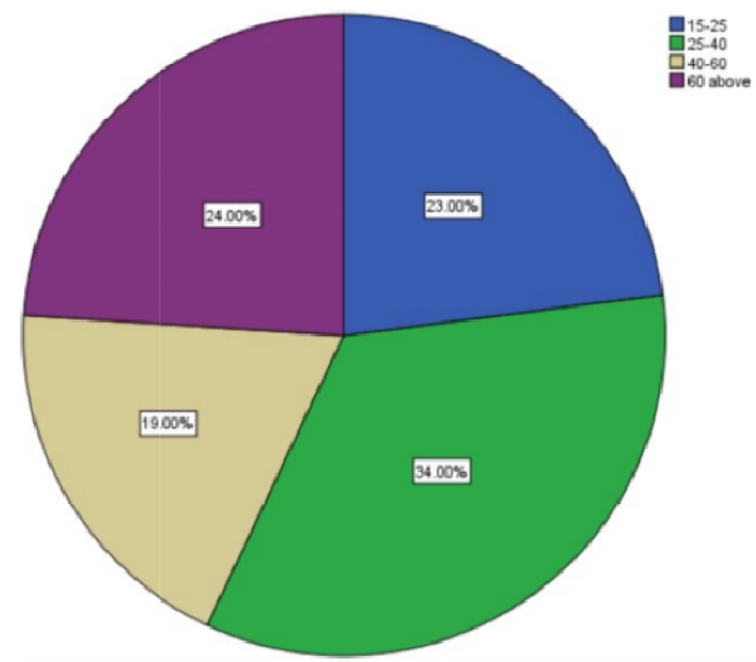

Figure 1: Pie chart representing percentage distribution of age group. $34 \%$ are in age group between $25-40$ (green); $19 \%$ are in age group above 40 (grey); about $23 \%$ are in age group between $15-25$ (blue); $24 \%$ are in age group above 60 Years. Majority of the $25-40$ years old age (34\%) group had participated in the survey (green).

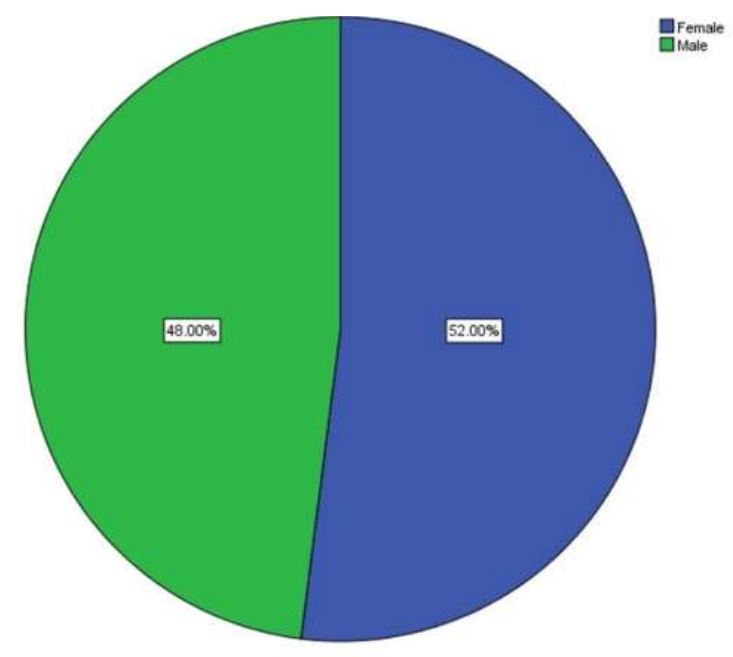

Figure 2: Pie chart showing percentage distribution of male and female participants, $52 \%$ of participant's are female (blue); $48 \%$ of participant's are male (green). Majority of females $(52 \%)$ had participated in the survey (blue).

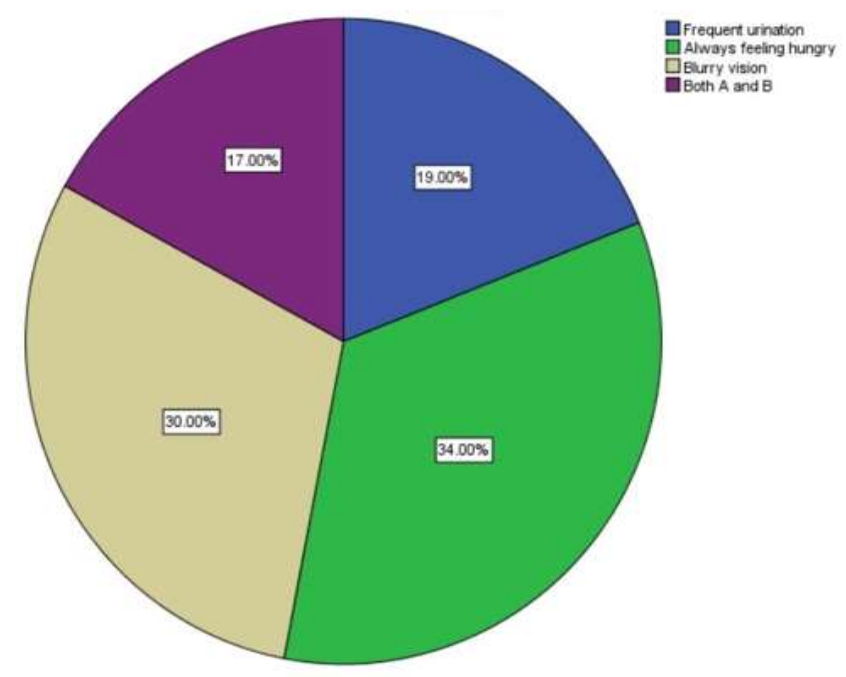

Figure-3: Pie chart showing percentage distribution of responses for symptoms in diabetes. $30 \%$ - blurry vision in diabetes (grey); 19\%- Polyuria (blue); 34\%- Polyphagia (green). Majority of participants (34\%) perceived that symptoms in diabetes were 'always feeling hungry' (green). 


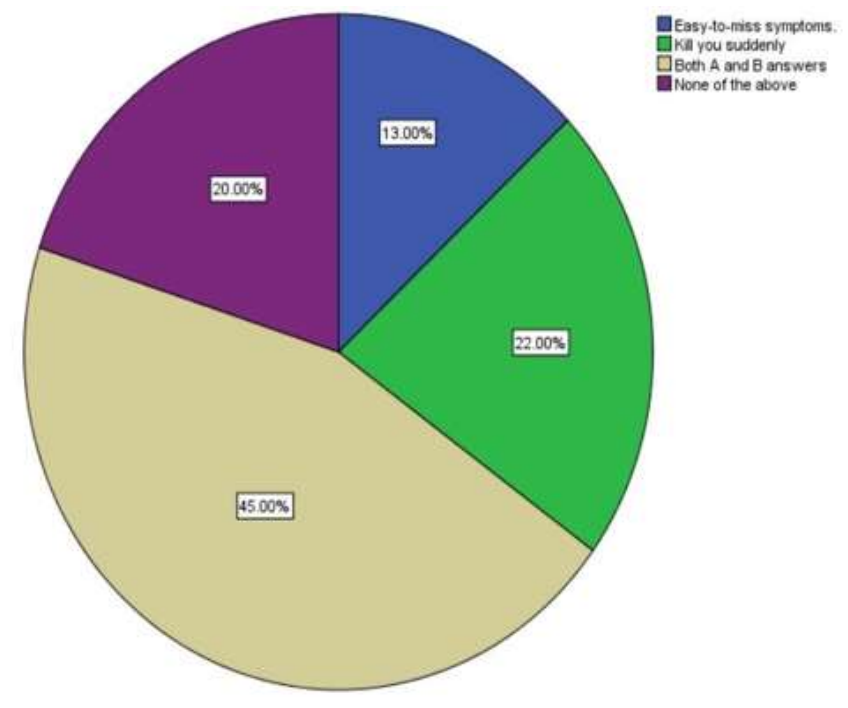

Figure-4: Pie chart showing percentage distribution of responses on diabetes called the silent killer, $45 \%$ - both $\mathrm{A}$ and B (grey); 22\%- kill suddenly (green); 13\%- easy to miss symptoms (blue). $45 \%$ believed diabetes is called a silent killer (grey). However the difference in response is less.

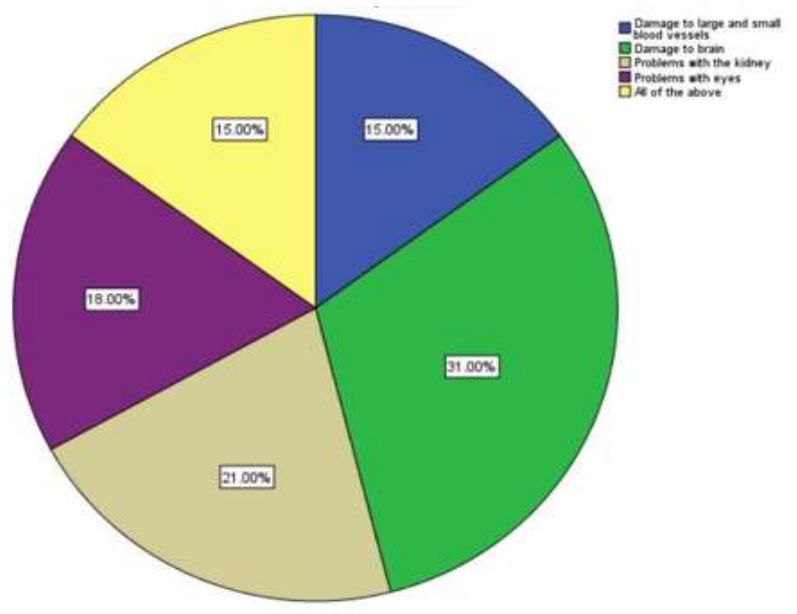

Figure-5: Pie chart showing percentage distribution of responses on harmful effects of diabetes. $21 \%$ - problems with kidney (grey); 31\%- damage to brain (green); 15\%-damage to large and small blood vessels (blue). 15\%- agreed All of the above (yellow). Majority of participants (31\%) were aware that diabetes causes damage to the brain (green) .

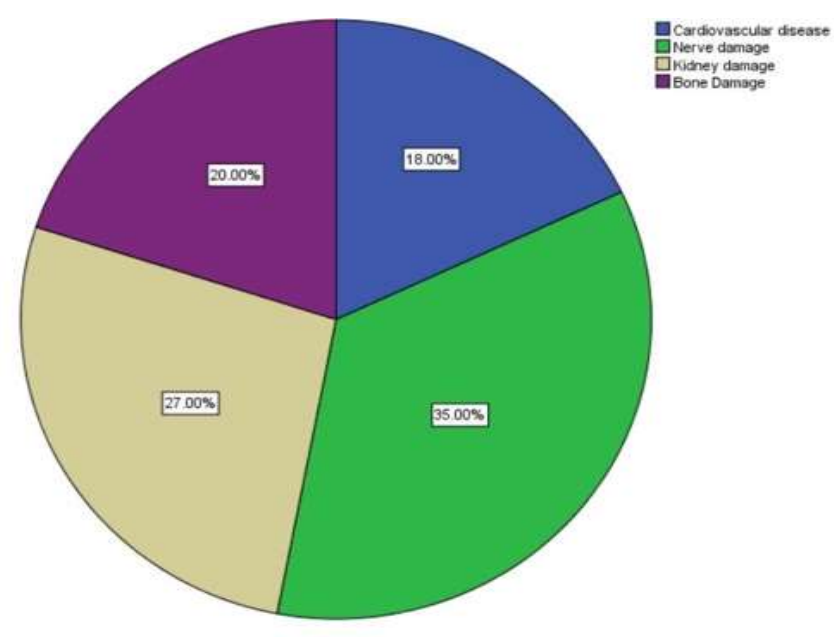

Figure-6: Pie chart showing percentage distribution of responses on common complication of diabetes. $35 \%$ - nerve damage (green); 27\%- agreed kidney damage (grey); 18\%- cardiovascular damage (blue). $20 \%$ - bone damage (violet). Majority of participants $(35 \%)$ were aware that diabetes leads to neuropathy (green). 


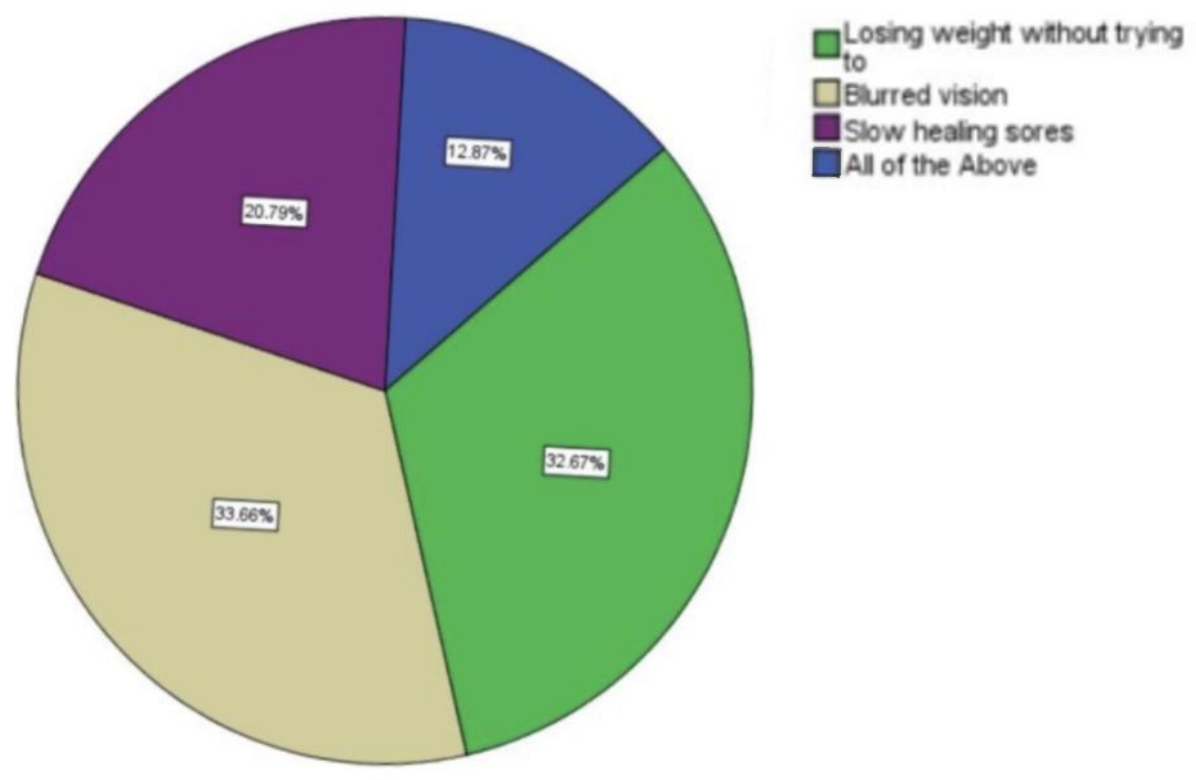

Figure-7: Pie chart showing percentage distribution of responses on common symptoms of undiagnosed diabetes. $33 \%$ - blurred vision (grey); 32\%- weight loss (green); $12 \%$ - all of the above (blue). $20 \%$ - agreed delayed wound healing (violet). $33 \%$ of participants were aware that increased blood sugar leads to blurred vision (grey).

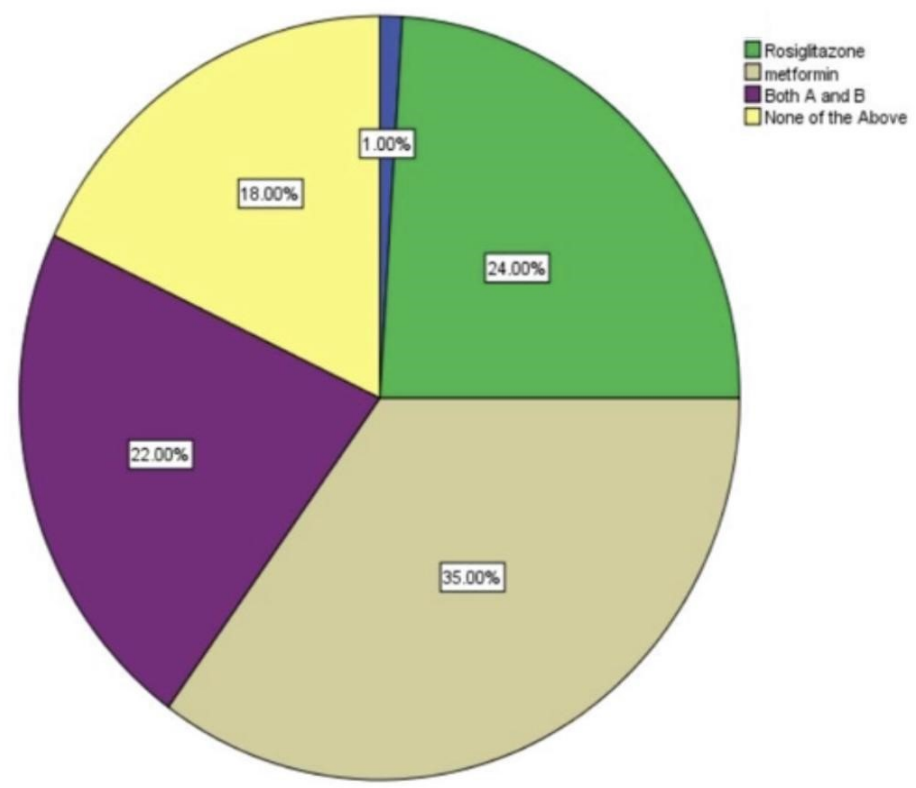

Figure-8: Pie chart showing percentage distribution of responses on medication for insulin resistance, $25 \%$ rosiglitazone (green); 35\%- metformin (grey); 18\%- none of the above (yellow). 22\%- both A and B (violet). 35\% of participants acknowledged metformin as the drug for insulin resistance (grey). However the difference in response is less. 


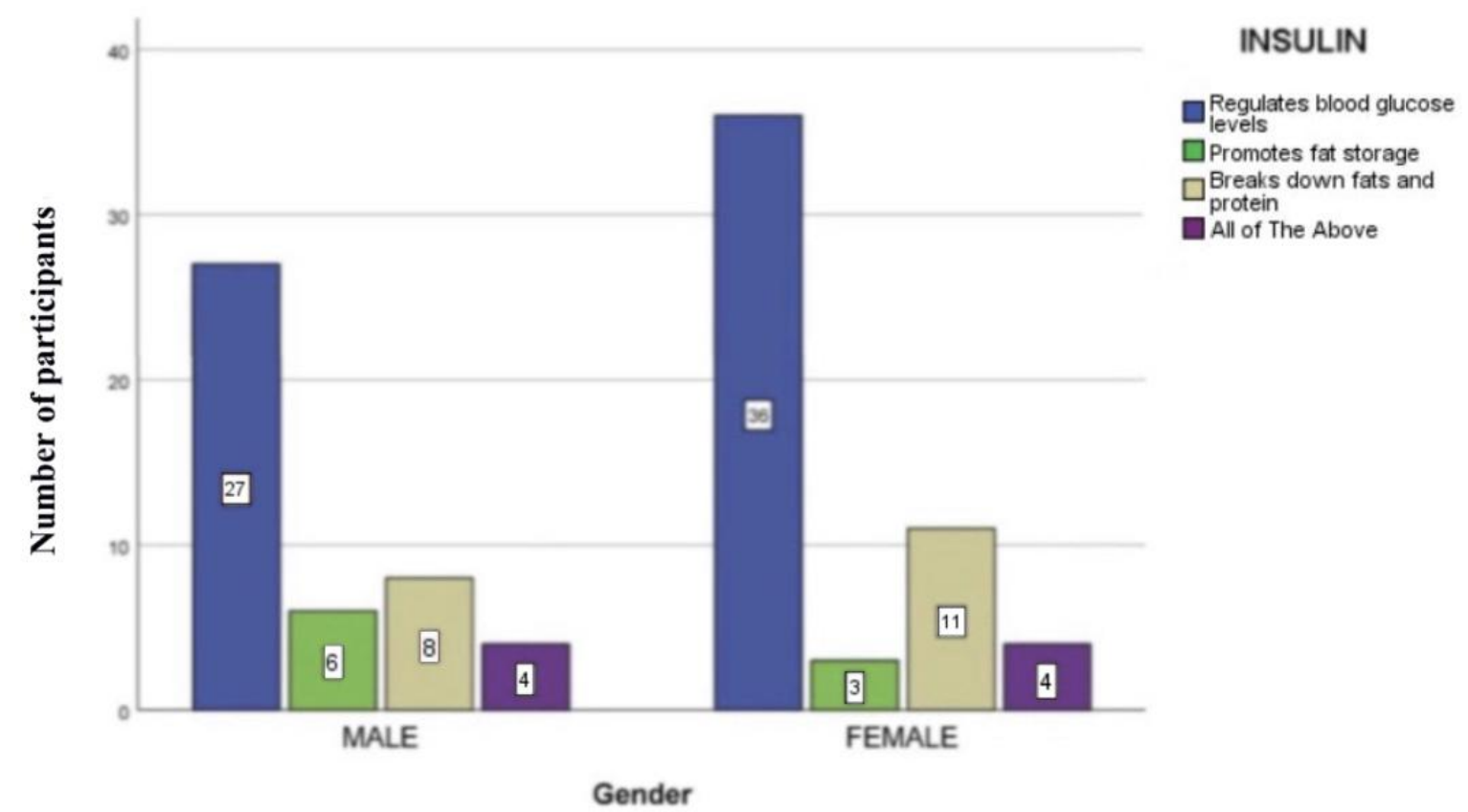

Figure-9: Bar graph showing the association between gender $(\mathrm{X}$ axis) and responses on role of insulin in diabetes $(\mathrm{Y}$ axis- No. of participants). $36 \%$ of females reported the role of insulin is to regulate blood glucose (blue) whereas only $27 \%$ of male reported the role of insulin is to regulate blood glucose (blue). Majority of females (36\%) and males

$(27 \%)$ knew that the role of insulin was "regulation of blood glucose". The analysis showed that the level of awareness among males and females was similar. Chi square value $=1.643 ; P$ value $=0.650(p>0.05$, hence statistically not significant).

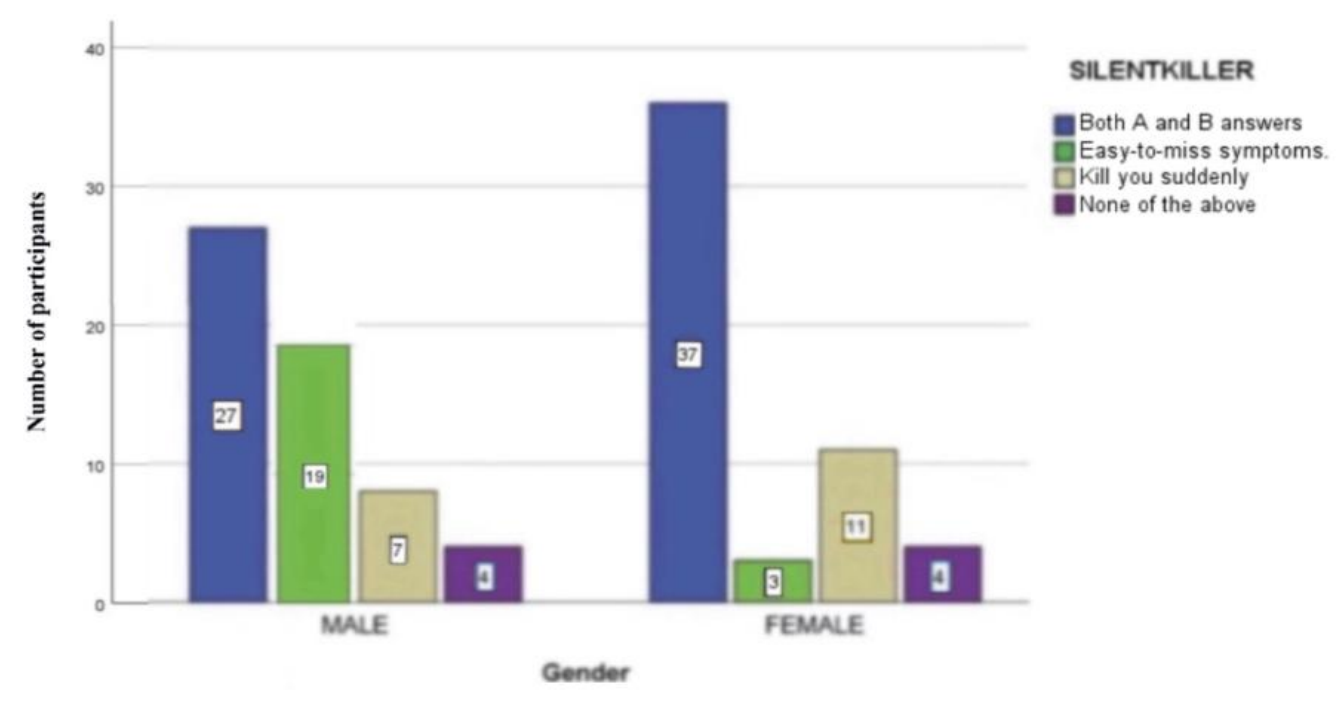

Figure-10: Bar graph showing the association between gender $(\mathrm{X}$ axis) and responses on diabetes as the silent killer (Y axis- No. of participants). Majority of females $(27 \%)$ and male(37\%) believed that diabetes is a silent killer because it is 'easy to miss symptoms and kill suddenly' (blue). Gender did not influence the level of awareness. Chi square value=3.318; $P$ value $=0.345$ ( $p>0.05$ statistically not significant $)$. 


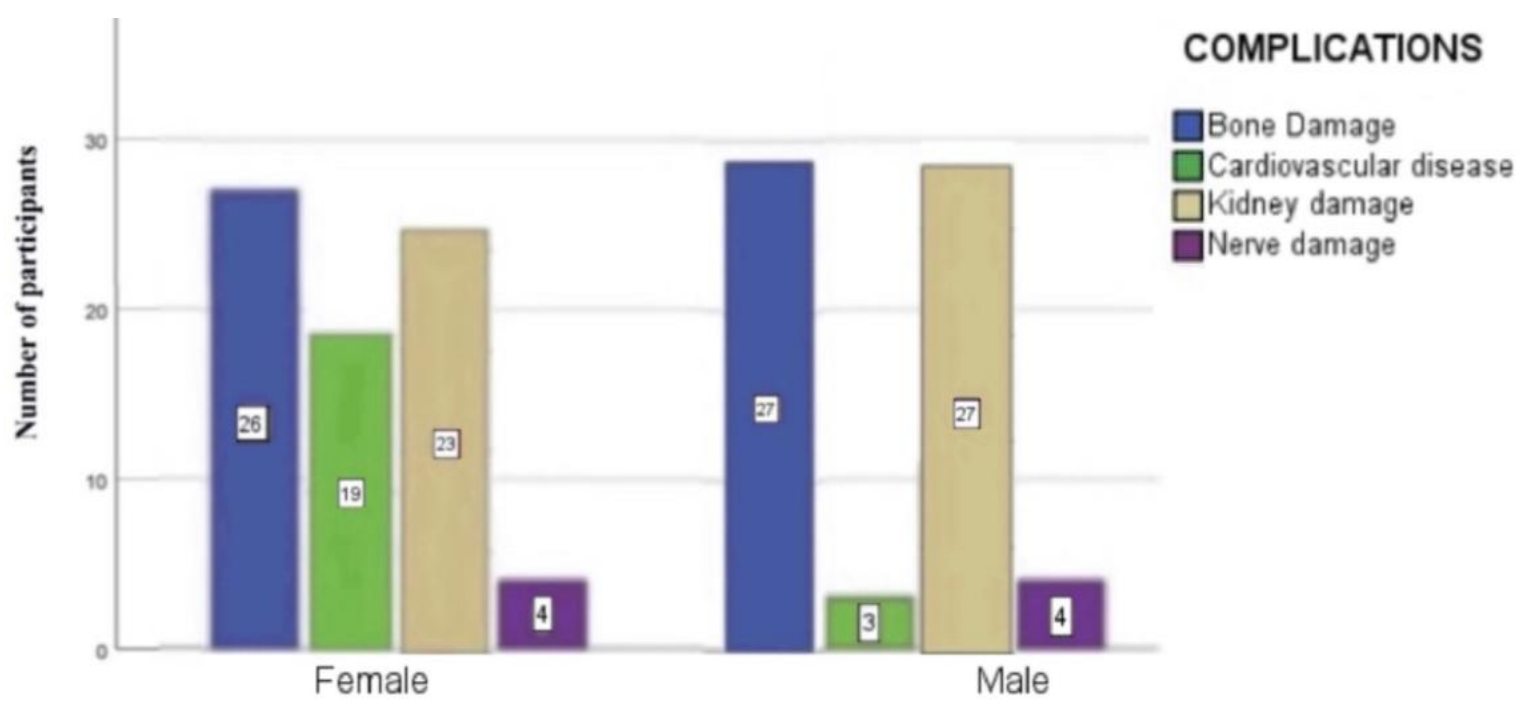

Gender

Figure-11: Bar graph showing the association between gender ( $\mathrm{X}$ axis) and responses on common complication of diabetes ( $\mathrm{Y}$ axis- No. of participants). $26 \%$ of females reported bone damage and $27 \%$ of male reported bone damage. Chi square value $=2.146 ; P$ value $=0.114$ ( $p>0.05$ statistically not significant). Males are more aware of complications in diabetes. Majority of males and female participants considered the common complication associated with diabetes mellitus was bone damage (blue) and kidney damage (grey). Gender did not influence the level of awareness.

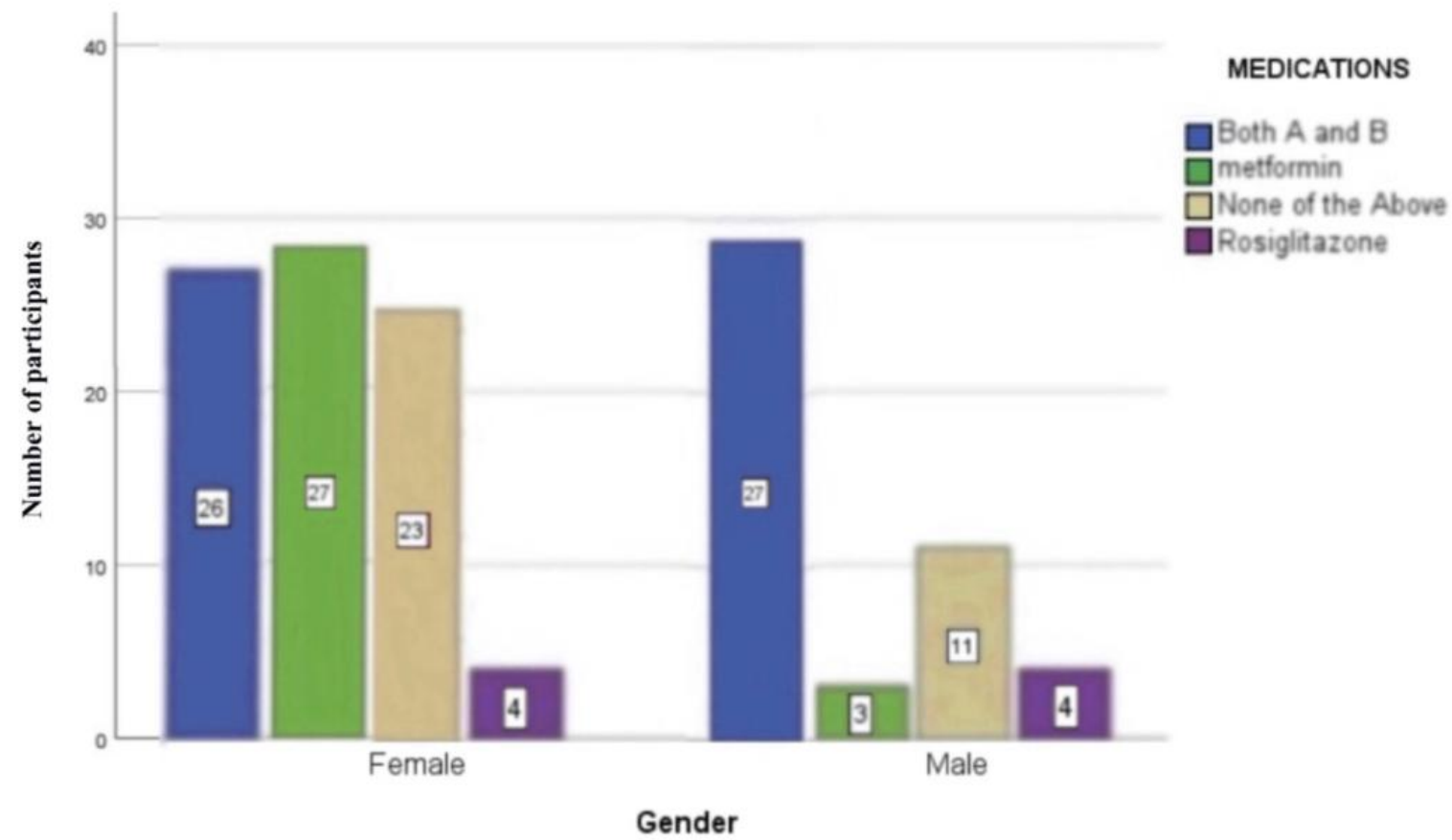

Figure-12: Bar graph showing the association between gender $(\mathrm{X}$ axis) and responses on medication for insulin resistance (Y axis- No. of participants). Majority of females $(27 \%)$ consider metformin as a medication for insulin resistance (green). Majority of male (27\%) consider metformin and rosiglitazone as a medication for insulin resistance (green). Chi square value $=1.321 ; \mathrm{P}$ value $=0.858$ ( $\mathrm{p}>0.05$ statistically not significant). The association between gender and responses on medication for insulin resistance is not statistically significant. 


\section{CONCLUSION}

The participants were aware of the symptoms associated with diabetes mellitus. Both male and female population were equally aware about diabetes mellitus. More awareness camps, workshops, may be conducted to create awareness on risk factors, complications of diabetes and its associated disorders. Awareness on lifestyle modifications is the need of the hour for both young and older generations.

The current study was done to analyze the knowledge and awareness of diabetes mellitus among the older generation and from the results we infer that the knowledge of diabetes mellitus can prevent the impending chronic comorbidities of diabetes mellitus. More awareness camps, workshops, may be conducted to create awareness on risk factors, complications of diabetes and its associated disorders. Awareness on lifestyle modifications is the need of the hour for both young and older generations.

\section{5, ACKNOWLEDGEMENT:}

We thank Saveetha Dental College for providing us the support to conduct the study.

\section{6, CONFLICT OF INTEREST:}

Nil

\section{REFERENCES:}

[1] Gregg EW. Is Diabetes Associated With Cognitive Impairment and Cognitive Decline Among Older Women? [Internet].
Vol. 160, Archives of Internal Medicine. 2000. p. 174. Available from: http://dx.doi.org/10.1001/archinte.160.2.1 74

[2] Yaffe K. Association Between Hypoglycemia and Dementia in a Biracial Cohort of Older Adults With Diabetes Mellitus [Internet]. Vol. 173, JAMA Internal Medicine. 2013. p. 1300. Available from: http://dx.doi.org/10.1001/jamainternmed. 2013.6176

[3] Bertoni AG, Hundley WG, Massing MW, Bonds DE, Burke GL, Goff DC Jr. Heart failure prevalence, incidence, and mortality in the elderly with diabetes. Diabetes Care. 2004 Mar;27(3):699-703.

[4] Junius-Walker U, Theile G, HummersPradier E. Prevalence and predictors of polypharmacy among older primary care patients in Germany. Fam Pract. 2007 Feb;24(1):14-9.

[5] Kumar A. India towards diabetes control: Key issues [Internet]. Vol. 6, Australasian Medical Journal. 2013. p. 524-31. http://dx.doi.org/10.4066/amj.2013.1791

[6] Lloyd-Sherlock P, Beard J, Minicuci N, Ebrahim S, Chatterji S. Hypertension among older adults in low- and middleincome countries: prevalence, awareness and control [Internet]. Vol. 43, International Journal of Epidemiology. 2014. p. 116-28. Available from: http://dx.doi.org/10.1093/ije/dyt215

[7] Gregg EW, Beckles GL, Williamson DF, Leveille SG, Langlois JA, Engelgau MM, et al. Diabetes and physical disability 
among older U.S. adults [Internet]. Vol. 23, Diabetes Care. 2000. p. 1272-7. http://dx.doi.org/10.2337/diacare.23.9.1272

[8] Koekkoek PS, Jaap Kappelle L, van den Berg E, Guy E H, Biessels GJ. Cognitive function in patients with diabetes mellitus: guidance for daily care [Internet]. Vol. 14, The Lancet Neurology. 2015. p. 329-40. http://dx.doi.org/10.1016/s14744422(14)70249-2

[9] Rubenstein LZ. Falls in older people: epidemiology, risk factors and strategies for prevention [Internet]. Vol. 35, Age and Ageing. 2006. p. ii37-41. Available from:

http://dx.doi.org/10.1093/ageing/af1084

[10] Sinclair A, Morley JE, Rodriguez-Mañas L, Paolisso G, Bayer T, Zeyfang A, et al. Diabetes Mellitus in Older People: Position Statement on behalf of the International Association of Gerontology and Geriatrics (IAGG), the European Diabetes Working Party for Older People (EDWPOP), and the International Task Force of Experts in Diabetes [Internet]. Vol. 13, Journal of the American Medical Directors Association. 2012. p. 497-502. http://dx.doi.org/10.1016/j.jamda.2012.04. 012

[11] Al-Baghli NA, Al-Turki KA, Al-Ghamdi AJ, Prasad K, Taha AZ, Al-Almaie SM. Evaluation of capillary blood glucose versus a high-risk questionnaire for screening for undiagnosed diabetes mellitus in Eastern province, Saudi Arabia [Internet]. Vol. 16, Eastern Mediterranean Health Journal. 2010. p. 1237-44. http://dx.doi.org/10.26719/2010.16.12.12 37

[12] Pandey S. Antibacterial And Antifungal Activities Of Ocimum gratissimum L [Internet]. Vol. 9, International Journal of Pharmacy and Pharmaceutical Sciences. 2017. p. 26. Available from: http://dx.doi.org/10.22159/ijpps.2017v9i1 2.22678

[13] Menon A, V Vp, Gayathri R. Preliminary Phytochemical Analysis And Cytotoxicity Potential Of Pineapple Extract On Oral Cancer Cell Lines [Internet]. Asian Journal Of Pharmaceutical And Clinical Research. 2016. P. 140. Available From: http://dx.doi.org/10.22159/ajpcr.2016.v9s 2.13313

[14] Henderson JN, Allen KV, Deary IJ, Frier BM. Hypoglycaemia in insulin-treated Type 2 diabetes: frequency, symptoms and impaired awareness [Internet]. Vol. 20, Diabetic Medicine. 2003. p. 1016-21. http://dx.doi.org/10.1046/j.14645491.2003.01072.x

[15] Foley DJ, Vitiello MV, Bliwise DL, Ancoli-Israel S, Monjan AA, Walsh JK. Frequent Napping Is Associated With Excessive Daytime Sleepiness, Depression, Pain, and Nocturia in Older Adults: Findings From the National Sleep Foundation "2003 Sleep in America" Poll [Internet]. Vol. 15, The American Journal of Geriatric Psychiatry. 2007. p. 344-50. http://dx.doi.org/10.1097/01.jgp.0000249 385.50101 .67

[16] Petersen PE, Yamamoto T. Improving the oral health of older people: the approach 
of the WHO Global Oral Health Programme [Internet]. Vol. 33, Community Dentistry and Oral Epidemiology. 2005. p. 81-92. Available from: http://dx.doi.org/10.1111/j.16000528.2004.00219.x

[17] Mühlhauser I, Overmann H, Bender R, Bott U, Jörgens $\mathrm{V}$, Trautner $\mathrm{C}$, et al. Social status and the quality of care for adult people with Type I (insulindependent) diabetes mellitus - a population-based study [Internet]. Vol. 41, Diabetologia. 1998. p. 1139-50. Available from: http://dx.doi.org/10.1007/s001250051043

[18] Ponnulakshmi R, Shyamaladevi B, Vijayalakshmi P, Selvaraj J. In silico and in vivo analysis to identify the antidiabetic activity of beta sitosterol in adipose tissue of high fat diet and sucrose induced type-2 diabetic experimental rats. Toxicol Mech Methods. 2019 May;29(4):276-90.

[19] Wu F, Zhu J, Li G, Wang J, Veeraraghavan VP, Mohan SK, et al. Biologically synthesized green gold nanoparticles from Siberian ginseng induce growth-inhibitory effect on melanoma cells (B16) [Internet]. Vol. 47, Artificial Cells, Nanomedicine, and Biotechnology. 2019. p. 3297-305. http://dx.doi.org/10.1080/21691401.2019. 1647224

[20] Ke Y, Al Aboody MS, Alturaiki W, Alsagaby SA, Alfaiz FA, Veeraraghavan VP, et al. Photosynthesized gold nanoparticles from Catharanthus roseus induces caspase-mediated apoptosis in cervical cancer cells (HeLa). Artif Cells Nanomed Biotechnol. 2019 Dec;47(1):1938-46.

[21] Wang Y, Zhang Y, Guo Y, Lu J, Veeraraghavan VP, Mohan SK, et al. Synthesis of Zinc oxide nanoparticles from Marsdenia tenacissima inhibits the cell proliferation and induces apoptosis in laryngeal cancer cells (Hep-2) [Internet]. Vol. 201, Journal of Photochemistry and Photobiology B: Biology. 2019. p. 111624. Available from: http://dx.doi.org/10.1016/j.jphotobiol.201 9.111624

[22] Gan H, Zhang Y, Zhou Q, Zheng L, Xie $\mathrm{X}$, Veeraraghavan VP, et al. Zingerone induced caspase-dependent apoptosis in MCF-7 cells and prevents 7,12-dimethylbenz(a)anthracene-induced mammary carcinogenesis in experimental rats [Internet]. Vol. 33, Journal of Biochemical and Molecular Toxicology. 2019. Available from: http://dx.doi.org/10.1002/jbt.22387

[23] Ma Y, Karunakaran T, Veeraraghavan VP, Mohan SK, Li S. Sesame Inhibits Cell Proliferation and Induces Apoptosis through Inhibition of STAT-3 Translocation in Thyroid Cancer Cell Lines (FTC-133) [Internet]. Vol. 24, Biotechnology and Bioprocess Engineering. 2019. p. 646-52. Available from: http://dx.doi.org/10.1007/s12257019-0151-1

[24] Li Z, Veeraraghavan VP, Mohan SK, Bolla SR, Lakshmanan H, Kumaran S, et 
al. Apoptotic induction and antimetastatic activity of eugenol encapsulated chitosan nanopolymer on rat glioma C6 cells via alleviating the MMP signaling pathway [Internet]. Vol. 203, Journal of Photochemistry and Photobiology B: Biology. 2020. p. 111773. Available from: http://dx.doi.org/10.1016/j.jphotobiol.201 9.111773

[25] Chen F, Tang Y, Sun Y, Veeraraghavan VP, Mohan SK, Cui C. 6-shogaol, a active constiuents of ginger prevents UVB radiation mediated inflammation and oxidative stress through modulating $\mathrm{NrF} 2$ signaling in human epidermal keratinocytes (HaCaT cells) [Internet]. Vol. 197, Journal of Photochemistry and Photobiology B: Biology. 2019. p. 111518. Available from: http://dx.doi.org/10.1016/j.jphotobiol.201 9.111518

[26] Rengasamy G, Venkataraman A, Veeraraghavan VP, Jainu M. Cytotoxic and apoptotic potential of Myristica fragrans Houtt. (mace) extract on human oral epidermal carcinoma KB cell lines [Internet]. Vol. 54, Brazilian Journal of Pharmaceutical Sciences. 2018. Available from: http://dx.doi.org/10.1590/s217597902018000318028

[27] G R, Ramya G, V VP, Gayathri R. Cytotoxicity Of Strawberry Extract On Oral Cancer Cell line [Internet]. Vol. 11, Asian Journal of Pharmaceutical and
Clinical Research. 2018. p. 353. http://dx.doi.org/10.22159/ajpcr.2018.v11 i9.25955

[28] Jainu M, Priya V, Mohan S. Biochemical evidence for the antitumor potential of Garcinia mangostana Linn. On diethylnitrosamine-induced hepatic carcinoma [Internet]. Vol. 14, Pharmacognosy Magazine. 2018. p. 186. http://dx.doi.org/10.4103/pm.pm_213_17

[29] Mohan SK, Veeraraghavan VP, Jainu M. Effect of pioglitazone, quercetin and hydroxy citric acid on extracellular matrix components in experimentally induced non-alcoholic steatohepatitis. Iran J Basic Med Sci. 2015 Aug;18(8):832-6.

[30] Shukri NMM, Vishnupriya V, Gayathri R, Mohan SK. Awareness in childhood obesity [Internet]. Vol. 9, Research Journal of Pharmacy and Technology. 2016. p. 1658. Available from: http://dx.doi.org/10.5958/0974360x.2016.00334.6

[31] Website [Internet]. [cited 2020 Jun 11]. Available from: Characterization, partial purification of alkaline protease from intestinal waste of scomberomorus guttatus and production of laundry detergent with alkaline protease additive. 10.5530/ijper.50.2.19 https://www.scopus.com/inward/record.ur 1? eid $=2$-s2.084983288616\&partnerID $=40 \& \mathrm{md} 5=85 \mathrm{ae}$ 0f43c92054de 2d24951796bde6ec 